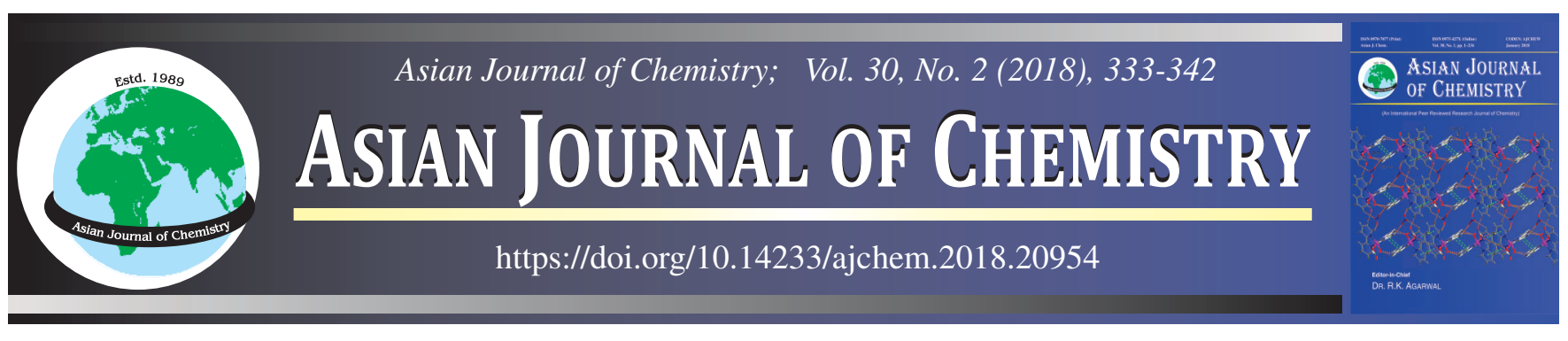

\title{
Design, Synthesis, Single X-Ray Crystal Structure, DFT and Molecular Docking Studies of Novel Clip Type-Pyridyltetrazole Analogues
}

\author{
M. SuRendra Babu' ${ }^{1}$, K. Santhosh Reddy ${ }^{1}$, Kalyan Sundar Ghosh ${ }^{2}$, \\ Bijaya Ketan Sahoo ${ }^{1}$, Ch. Himasekar ${ }^{3}$ and Shaik Mustafa, ${ }^{1, *}$
}

\author{
${ }^{1}$ Department of Chemistry, GITAM Deemed to be University, Hyderabad Campus, Rudaram, Sangareddy-502 329, India \\ ${ }^{2}$ Department of Chemistry, National Institute of Technology, Hamirpur-177 005, India \\ ${ }^{3}$ Department of Chemistry, Rayalaseema University, Kurnool-518 002, India \\ *Corresponding author: E-mail: mustaff_02@yahoo.co.in
}

Novel clip type-pyridyltetrazole analogs of 1,3-bis(5-(pyridin-2-yl)- $1 H$-tetrazol-1-yl)propan-2-ol (3A) and 1,3-bis(5-(pyridin-2-yl)-2Htetrazol-2-yl) propan-2-ol (3B) have been synthesized by the reaction of 2-(1H-tetrazol-5-yl)pyridine (2) with 0.5 equivalent of epichlorohydrine in DMF using $\mathrm{K}_{2} \mathrm{CO}_{3}$ as a base. Relevant monomers of 1-chloro-3-(5-(pyridin-2-yl)- $1 H$-tetrazol-1-yl)propan-2-ol (3C) and 1-chloro-3-(5-(pyridin-2-yl)-2H-tetrazol-2-yl)propan-2-ol (3D) have been synthesized by reaction of compound 2 with one equivalent of epichlorohydrine in DMF using $\mathrm{K}_{2} \mathrm{CO}_{3}$ as a base. The compounds $\mathbf{3 C}$ and $\mathbf{3 D}$ are further modified by the reaction sequences to obtain the ligands 1-(2-(hydroxymethyl)phenoxy)-3-(5-(pyridin-2-yl)-1H-tetrazol-1-yl)propan-2-ol (3G) and 1-(2-(hydroxymethyl)phenoxy)3-(5-(pyridin-2-yl)-2 $\mathrm{H}$-tetrazol-2-yl)propan-2-ol (3H) respectively. The eight synthesized compounds $(\mathbf{3 A}-\mathbf{3 H})$ were characterized by ${ }^{1} \mathrm{H}$ NMR, ${ }^{13} \mathrm{C}$ NMR, IR and Mass spectroscopy. The compound 3A, was crystallized in triclinic primitive system space group P2(1)/c with a $=8.9442 \AA, \mathrm{b}=9.2097 \AA, \mathrm{c}=11.3558 \AA, \mathrm{V}=814.68 \AA, \mathrm{R} 1=0.0213$ at $298 \mathrm{~K}$. The compounds 3A and 3B were optimized, HOMO/ LUMO and molecular electrostatic potential studies were carried by DFT calculations with B3LYP/6.311G** method. The molecular docking studies were performed on $\mathbf{3 A}, \mathbf{3 B}, \mathbf{3 G}$ and $\mathbf{3 H}$ and the studies reveal that all the compounds exist in crescent shapes.

Keywords: Clip type-pyridyltetrazole, Epichlorohydrine, Salicylaldehyde, DFT studies, Molecular docking.

\section{INTRODUCTION}

Tetrazoles are the class of heterocyclic polyazoles containing four nitrogen's and a carbon atom. The chemistry of tetrazole has obtained extensive development, because tetrazoles and their derivatives have various potential applications in coordination chemistry as ligand due to their multiple $\mathrm{N}$ donar atoms and rich coordination modes [1]. Due to the high enthalpy of formation, tetrazole decomposition results in the liberation of two nitrogen molecules and a significant amount of energy. Tetrazole and their derivatives are reported to show various biological activities like antibacterial, antifungal, anticonvulsant, analgesic, anti-inflammatory, antitubercular, anticancer, antihypertensive and antidiabetic activities [2]. Tetrazoles are important synthons in synthetic organic chemistry and also used as pre-cursors of carbenes in flash vacuum pyrolysis [3]. The nitrogen rich ring system is used as explosives [4] and pharmaceuticals [5].

Besides, tetrazoles could be used as components of new generation filtering materials for the purification of biological fluids (blood, lymph etc.) from heavy metal ions [6]. Various tetrazole-based compounds have also shown good coordination properties and are able to form stable complexes with several metal ions [7]. The pyridine tetrazoles exhibit a strong fluorescence enhancement upon gel formation [8]. The tetrazole coordination compounds form various structures exist as one-, two- or three-dimensional coordination polymers and shown to form a three-dimensional (3D) framework by hydrogen bonds [9]. The tetrazole-containing uranium(VI) complexes were prepared by incorporating the oxygen-containing substituent at the tetrazole ring [10]. A 3D metal organic framework containing tetrazole functionalized aromatic carboxylic acid has been synthesized and shown to exhibit capability for the sorption of different gases [11]. Recently pyridyl-tetrazole ligands containing ester or carboxylate pendant arms were shown to form metal organic frame works [12]. Recently, we have described the synthesis of pyridyl-tetrazole compounds containing hydroxyl and dimethylamine pendant arms and examined their coordination chemistry with $\mathrm{Cu}$ (II) metal [13]. As part of our current investigations into the synthesis of novel pyridyl- 
tetrazole derivatives, we have altered the pendant arm and synthesized eight novel ligands in which six compounds are clip type [14] pyridyl tetrazole analogues. The coordination studies of these ligands with metal salts are ongoing.

\section{EXPERIMENTAL}

Picolinonitrile and epichlorohydrine were purchased from Sigma-Aldrich. The solvents used in the synthesis of the ligands and metal complexes were distilled before use. All other chemicals were of AR grade and were used without further purification. All melting points were obtained on Elico instrument, India (modelMP96) and are uncorrected. Q1MSQ1/auto injection mass spectra were performed using a Pexciex API $2000 \mathrm{eV}$ spectrometer. NMR spectra were recorded on Bruker Top Spin Instrument. IR spectra were recorded using Bruker Alpha T OPUS instrument.

Synthesis of 2-(1H-tetrazol-5-yl)pyridine (2): A suspension of 2-cyanopyridine ( $10 \mathrm{~g}, 96 \mathrm{mmol})$, sodium azide (12.5 g, $192 \mathrm{mmol})$, ammonium chloride (10.3 g, $192 \mathrm{mmol}$ ) and lithium chloride ( $2 \mathrm{~g}, 48 \mathrm{mmol})$ in anhydrous dimethylformamide (100 $\mathrm{mL}$ ) was stirred for $10 \mathrm{~h}$ at $110{ }^{\circ} \mathrm{C}$. The solution was cooled and the insoluble salts were removed by filtration. The solvent was evaporated under reduced pressure and then the residue was dissolved in deionized water $(200 \mathrm{~mL})$ and acidified with concentrated $\mathrm{HCl}(3 \mathrm{~mL})$, to initiate precipitation. The product was removed by filtration, washed with water $(30-40 \mathrm{~mL})$ and dried to give a brown solid, which was recrystallized from hot ethanol to give 2 as brown needles, yield: $54 \%$. m.p.: 221$223{ }^{\circ} \mathrm{C}$; ${ }^{1} \mathrm{H}$ NMR (DMSO- $\left.d_{6}\right): 8.56(\mathrm{~d}, 1 \mathrm{H}, J=7.9 \mathrm{~Hz}),$, $(\mathrm{d}, 1 \mathrm{H}, J=7.8 \mathrm{~Hz}$ ), 7.79 (t, $1 \mathrm{H}, J=7.8 \mathrm{~Hz}$ ), 7.26 (t, 1H, $J=$ $7.9 \mathrm{~Hz},), 7.1$ (s, 1H) ppm.

Syntheses of 1,3-bis[5-(pyridin-2-yl)-1H-tetrazol-1-yl]propan-2-ol (3A) and 1-[5-(pyridin-2-yl)-1H-tetrazol-1-yl]3-[5-(pyridin-2-yl)-2H-tetrazol-2-yl]propan-2-ol (3B): To a solution of tetrazole (2) $(2 \mathrm{~g}, 13.6 \mathrm{mmol})$ dissolved in dimethyl fomamide $(25 \mathrm{~mL})$ was added epichlorohydrine $(0.5 \mathrm{~mL}, 6.8$ $\mathrm{mmol})$ followed by potassium carbonate $(3.7 \mathrm{~g}, 27.2 \mathrm{mmol})$. The resultant suspension was stirred at $70{ }^{\circ} \mathrm{C}$ for $12 \mathrm{~h}$. The reaction mixture was filtered and the solvent was evaporated under reduced pressure and the crude mass was diluted with ethyl acetate $(100 \mathrm{~mL})$ and the organic layer was washed successively with water $(50 \mathrm{~mL} \times 3)$ followed by brine solution. The organic layer was dried over $\mathrm{MgSO}_{4}$ and the solvent was evaporated under reduced pressure to yield a crude gummy oil which was purified by column chromatography on silica gel using hexane/EtOAc $(4: 1 \mathrm{v} / \mathrm{v})$ to elute first the compound 3A followed by compound 3B $(520 \mathrm{mg}, 2.1 \mathrm{mmol})$ along with inseparable mixture of other compounds.

Compound 3A: Off white solid, yield: $21 \%$. m.p.: 179$183{ }^{\circ} \mathrm{C}$; IR spectra $\left(\mathrm{KBr}, \mathrm{v}_{\max }, \mathrm{cm}^{-1}\right): 3134.5,2926.8,2855.0$, 1592.9, 1400.5, 1330.6, 1112.6, 1071.6, 703.7, 449.1; ${ }^{1} \mathrm{H}$ NMR $\left(\mathrm{CDCl}_{3}, 300 \mathrm{MHz}\right): \delta 8.61(\mathrm{dd}, 1 \mathrm{H}, J=4.2,0.6 \mathrm{~Hz}), 8.34$ $(\mathrm{d}, 1 \mathrm{H}, J=8.1 \mathrm{~Hz}), 7.94(\mathrm{td}, 1 \mathrm{H}, J=7.8,1.8 \mathrm{~Hz}), 7.52-7.45$ (m, 1H), 5.87-5.83 (m, 1H), 5.31-4.30 (m, 3H), 2.10-1.99 $(\mathrm{m}, 1 \mathrm{H}), 1.45-1.25(\mathrm{~m}, 11 \mathrm{H}), 0.87(\mathrm{t}, 1 \mathrm{H}, J=13.2,6.3 \mathrm{~Hz})$ ppm; ${ }^{13} \mathrm{C} \mathrm{NMR}\left(\mathrm{CDCl}_{3}, 75 \mathrm{MHz}\right): \delta 153.25,149.34,138.31$, $126.05,125.21,114.21,69.73,51.96$ ppm; MS: $\mathrm{m} / \mathrm{z}$ value $351.1(\mathrm{M}+1)$.
Compound 3B: Off white solid, yield: $15 \%$. m.p.: 168$173{ }^{\circ} \mathrm{C}$; IR spectra $\left(\mathrm{KBr}, v_{\max }, \mathrm{cm}^{-1}\right): 3235.3,2828.9,2755.5$, 1594.8, 1333.8, 1328.8, 1111.8, 1077.0, 714.3, 458.1; ${ }^{1} \mathrm{H}$ NMR $\left(\mathrm{CDCl}_{3}, 300 \mathrm{MHz}\right): \delta 8.76(\mathrm{~d}, 1 \mathrm{H}, J=3.9 \mathrm{~Hz}), 8.55(\mathrm{~d}, 1 \mathrm{H}, J=$ $5.1 \mathrm{~Hz}), 8.33(\mathrm{~d}, 1 \mathrm{H}, J=8.1 \mathrm{~Hz}), 8.25(\mathrm{~d}, 1 \mathrm{H}, J=7.8 \mathrm{~Hz}), 7.97$ $(\mathrm{td}, 1 \mathrm{H}, J=7.8,1.8 \mathrm{~Hz}), 7.87(\mathrm{td}, 1 \mathrm{H}, J=7.8,1.8 \mathrm{~Hz}), 7.5-7.39$ $(\mathrm{m}, 2 \mathrm{H}), 5.90(\mathrm{~s}, 1 \mathrm{H}), 5.2-4.93(\mathrm{~m}, 5 \mathrm{H}), 1.43(\mathrm{t}, 1 \mathrm{H}, J=10.2$, $5.7 \mathrm{~Hz}), 1.43-1.24(\mathrm{~m}, 13 \mathrm{H}), 0.87(\mathrm{t}, 2 \mathrm{H}, J=13.2,6.3 \mathrm{~Hz}) \mathrm{ppm}$; ${ }^{13} \mathrm{C} \mathrm{NMR}\left(\mathrm{CDCl}_{3}, 75 \mathrm{MHz}\right): \delta 165.12,152.92,150.43,149.13$, 146.63, 143.96, 138.71, 137.37, 126.25, 125.51, 125.18, 122.75, 114.20, 69.10, 56.70, 51.63 ppm; MS: $m / z$ value $351.1(\mathrm{M}+1)$.

Syntheses of 1-chloro-3-[5-(pyridin-2-yl)-1H-tetrazol1-yl]propan-2-ol (3C) and 1-chloro-3-[5-(pyridin-2-yl)-2Htetrazol-2-yl]propan-2-ol (3D): The same procedure, workup and purification methods which were used to prepare $\mathbf{3 A}$ and 3B were followed to prepare the compounds $\mathbf{3 C}$ and $\mathbf{3 D}$ except 1.0 equivalents of epichlorohydrine was used instead of 0.5 equivalent of it with respect to the tetrazole $2(2 \mathrm{~g}, 13.6 \mathrm{mmol})$. The column chromatography of the crude material using $\mathrm{CHCl}_{3}$ and $\mathrm{MeOH}(19: 1 \mathrm{v} / \mathrm{v})$ was eluted first the compound $3 \mathrm{C}$ followed by compound 3D along with inseparable mixture of other compounds.

Compound 3C: Off white solid, yield: $32 \%$. m.p.: 83$88^{\circ} \mathrm{C}$; IR spectra $\left(\mathrm{KBr}, \mathrm{v}_{\max }, \mathrm{cm}^{-1}\right): 3319.9,2933.2,2501.4$, 2103.8, 1691.0, 1592.8, 1533.8, 1437.6, 1352.3, 1197.8, 752.7, 457.0; ${ }^{1} \mathrm{H}$ NMR $\left(\mathrm{CDCl}_{3}, 300 \mathrm{MHz}\right): \delta 8.74(\mathrm{~d}, 1 \mathrm{H}, J=4.2$ $\mathrm{Hz}), 8.37(\mathrm{~d}, 1 \mathrm{H}, J=7.8 \mathrm{~Hz}), 8.02(\mathrm{td}, 1 \mathrm{H}, J=7.8,1.5 \mathrm{~Hz})$, $7.62-7.55(\mathrm{~m}, 1 \mathrm{H}), 5.83(\mathrm{~d}, 1 \mathrm{H}, J=5.1 \mathrm{~Hz}), 5.20-4.80(\mathrm{~m}$, $2 \mathrm{H}), 4.46-4.40(\mathrm{~m}, 1 \mathrm{H}), 3.62(\mathrm{dd}, 1 \mathrm{H}, J=12.6,5.1 \mathrm{~Hz}), 3.44$ (dd, $1 \mathrm{H}, J=12.9,4.8 \mathrm{~Hz}) \mathrm{ppm} .{ }^{13} \mathrm{C} \mathrm{NMR}\left(\mathrm{CDCl}_{3}, 75 \mathrm{MHz}\right)$ : $\delta$ 152.95, 149.10, 143.89, 138.83, 126.33, 125.56, 70.29, 54.25, $51.66 \mathrm{ppm}$. MS: $\mathrm{m} / \mathrm{z}$ value $240.6(\mathrm{M}+1)$.

Compound 3D: Off white solid, yield: $29 \%$. m.p.: 68$73{ }^{\circ} \mathrm{C}$; IR spectra $\left(\mathrm{KBr}, \mathrm{v}_{\max }, \mathrm{cm}^{-1}\right): 3420.1,2814.5,2726.9$, 2104.4, 1593.9, 1351.0, 935.7, 763.4, 470.8; ${ }^{1} \mathrm{H} \mathrm{NMR}\left(\mathrm{CDCl}_{3}\right.$, $300 \mathrm{MHz}): \delta 8.72(\mathrm{~d}, 1 \mathrm{H}, J=4.5 \mathrm{~Hz}), 8.17(\mathrm{~d}, 1 \mathrm{H}, J=7.8$ $\mathrm{Hz}), 7.85$ (td, $1 \mathrm{H}, J=7.8,1.5 \mathrm{~Hz}), 7.44-7.38(\mathrm{~m}, 1 \mathrm{H}), 4.92-$ $4.78(\mathrm{~m}, 2 \mathrm{H}), 4.67-4.58(\mathrm{~m}, 1 \mathrm{H}), 4.16(\mathrm{~s}, 1 \mathrm{H}), 3.61-3.47(\mathrm{~m}$, $2 \mathrm{H}) \mathrm{ppm} ;{ }^{13} \mathrm{C} \mathrm{NMR}\left(\mathrm{CDCl}_{3}, 75 \mathrm{MHz}\right): \delta 164.59,150.06$, $146.15,137.52,125.23,122.63,69.04,56.66,53.91$ ppm; MS: $\mathrm{m} / \mathrm{z}$, value $240.06(\mathrm{M}+1)$.

Syntheses of 2-(2-hydroxy-3-(5-(pyridin-2-yl)-1Htetrazol-1-yl)propoxy)benzaldehyde (3E) and 2-(2-hydroxy3-(5-(pyridin-2-yl)-2H-tetrazol-2-yl)propoxy)benzaldehyde (3F): Chloro compound 3C or 3D (1g, $4.2 \mathrm{mmol}$ ) was dissolved in dimethyl formamide $(30 \mathrm{~mL})$ and cinnamaldehyde $(0.51 \mathrm{~g}$, $4.2 \mathrm{mmol})$ followed by $\mathrm{K}_{2} \mathrm{CO}_{3}(1.1 \mathrm{~g}, 8.4 \mathrm{mmol})$ was added. The resultant suspension was stirred at $70{ }^{\circ} \mathrm{C}$ for $16 \mathrm{~h}$. The reaction mixture was diluted with water and the crude product was extracted with ethyl acetate $(60 \mathrm{~mL})$ and the organic layer was washed successively with water $(50 \mathrm{~mL} \times 3)$ followed by brain solution. The organic layer was dried over $\mathrm{MgSO}_{4}$ and the solvent was evaporated under reduced pressure to get yellow colour solids $\mathbf{3 E}$ and $\mathbf{3 F}$ respectively. The solids were triturated with diethyl ether:hexane solution $(1: 1, \mathrm{v} / \mathrm{v})$ and utilized them without further purifications.

Compound 3E: yellowish solid, yield: $98 \%$. m.p.: $97^{\circ} \mathrm{C}$; Anal. Calc (\%). for $\mathrm{C}_{16} \mathrm{H}_{15} \mathrm{~N}_{5} \mathrm{O}_{3}$ (325.32): C, 59.07; H, 4.65; 
O, 14.75; N, 21.53. Found (\%): C, 59.03; H, 4.61; O, 14.74;

$\mathrm{N}, 21.58 ;{ }^{1} \mathrm{H}$ NMR (DMSO-d $\left.d_{6}, 300 \mathrm{MHz}\right): \delta 10.40(\mathrm{~s}, 1 \mathrm{H})$, $8.72(\mathrm{~d}, 1 \mathrm{H}, J=4.2 \mathrm{~Hz}), 8.21(\mathrm{~d}, 1 \mathrm{H}, J=8.1 \mathrm{~Hz}), 8.06(\mathrm{td}$, $1 \mathrm{H}, J=1.5-7.8 \mathrm{~Hz}), 7.72-7.53(\mathrm{~m}, 4 \mathrm{H}), 7.19(\mathrm{~d}, 1 \mathrm{H}, J=8.4$ $\mathrm{Hz}), 7.15-6.92(\mathrm{~m}, 2 \mathrm{H}), 5.59(\mathrm{~d}, 1 \mathrm{H}, J=6 \mathrm{~Hz}), 5.19(\mathrm{~d}, 2 \mathrm{H}, J$ $=6.6 \mathrm{~Hz}), 4.48-4.37(\mathrm{~m}, 1 \mathrm{H}), 4.24-4.12(\mathrm{~m}, 3 \mathrm{H}), 4.03(\mathrm{q}, 1 \mathrm{H}$, $J=19.2 \mathrm{~Hz}) \mathrm{ppm} ;{ }^{13} \mathrm{C}$ NMR (DMSO- $\left.d_{6}, 75 \mathrm{MHz}\right): \delta 189.42$, $160.66,152.31,149.54,144.34,138.16,136.37,127.40$, $125.85,124.40,124.33,120.90,113.42,70.07,67.40,51.63$ ppm; MS: $m / z$ value $326.13(\mathrm{M}+1)$.

Compound 3F: yellowish solid, yield: $99 \%$. m.p.: $84{ }^{\circ} \mathrm{C}$; Anal. Calc (\%). for $\mathrm{C}_{16} \mathrm{H}_{15} \mathrm{~N}_{5} \mathrm{O}_{3}$ (325.32): C, 59.07; H, 4.65; $\mathrm{O}, 14.75 ; \mathrm{N}, 21.53$. Found (\%): C, 59.01; H, 4.62; O, 14.71; $\mathrm{N}, 21.50 ;{ }^{1} \mathrm{H}$ NMR (DMSO- $d_{6}, 300 \mathrm{MHz}$ ): $\delta 10.48(\mathrm{~s}, 1 \mathrm{H})$, $8.75(\mathrm{~d}, 1 \mathrm{H}, J=3.3 \mathrm{~Hz}), 8.14(\mathrm{~d}, 1 \mathrm{H}, J=7.8 \mathrm{~Hz}), 8.01(\mathrm{td}$, $1 \mathrm{H}, J=1.5-7.8 \mathrm{~Hz}), 7.75-7.64(\mathrm{~m}, 2 \mathrm{H}), 7.56(\mathrm{dt}, 1 \mathrm{H}, J=6.6-$ 4.8), $7.26(\mathrm{~d}, 1 \mathrm{H}, J=8.4 \mathrm{~Hz}), 7.11(\mathrm{t}, 1 \mathrm{H}, J=15-7.5 \mathrm{~Hz})$, 7.07-6.87 (m, 1H), $5.78(\mathrm{~d}, 1 \mathrm{H}, J=6 \mathrm{~Hz}), 5.10-4.90(\mathrm{~m}, 2 \mathrm{H})$, $4.59-4.54(\mathrm{~m}, 1 \mathrm{H}), 4.26(\mathrm{t}, 2 \mathrm{H}, J=8.4-3.6 \mathrm{~Hz}), 4.03$ (q, 2H, $J$ $=6.9 \mathrm{~Hz}), 1.99(\mathrm{~s}, 3 \mathrm{H}) \mathrm{ppm} ;{ }^{13} \mathrm{C}$ NMR $\left(\mathrm{DMSO}-d_{6}, 75 \mathrm{MHz}\right)$ : $\delta 189.62,160.66,150.13,146.31,137.57,136.37,127.63$, 125.17, 124.46, 122.33, 120.99, 113.60, 70.08, 67.37, 59.73, 56.03 ppm; MS: $m / z$ value $326.13(\mathrm{M}+1)$

Syntheses of 1-[2-(hydroxymethyl)phenoxy]-3-[5(pyridin-2-yl)-1H-tetrazol-1-yl]propan-2-ol (3G) and 1-[2(hydroxymethyl)phenoxy]-3-[5-(pyridin-2-yl)-2H-tetrazol2-yl]propan-2-ol (3H): To a solution of aldehyde $\mathbf{3 E}$ or $\mathbf{3 F}$ (487 mg, $1.5 \mathrm{mmol})$ in methanol $(25 \mathrm{~mL})$ at $0{ }^{\circ} \mathrm{C}$ was added $\mathrm{NaBH}_{4}(29 \mathrm{mg}, 0.75 \mathrm{mmol})$ and the resultant mixture was stirred for $30 \mathrm{~min}$ at room temperature. The reaction mixture was quenched with aqueous ammonium chloride. Methanol was evaporated under reduced pressure and the compound was extracted with ethyl acetate $(60 \mathrm{~mL})$ and the organic layer was washed successively with water $(50 \mathrm{~mL} \times 3)$ followed by brain solution $(50 \mathrm{~mL})$. The organic layer was dried over $\mathrm{MgSO}_{4}$ and the solvent was evaporated under reduced pressure to get colourless solids $\mathbf{3 G}$ and $\mathbf{3 H}$ respectively. The solids were triturated with diethyl ether and utilized without further purifications.

Compound 3G: Colourless solid, yield: $99 \%$. m.p.: $141{ }^{\circ} \mathrm{C}$. Anal. calc. (\%). for $\mathrm{C}_{16} \mathrm{H}_{17} \mathrm{~N}_{5} \mathrm{O}_{3}$ (325.32): C, 58.71; H, 5.23; O, 14.66; N, 21.39. Found(\%): C, 58.69; H, 5.20; O, 14.70; $\mathrm{N}, 21.38 .{ }^{1} \mathrm{H}$ NMR (DMSO- $\left.d_{6}, 300 \mathrm{MHz}\right): \delta 8.74(\mathrm{~d}, 1 \mathrm{H}, J=$ $4.5 \mathrm{~Hz}), 8.22(\mathrm{~d}, 1 \mathrm{H}, J=7.8 \mathrm{~Hz}), 8.07(\mathrm{td}, 1 \mathrm{H}, J=7.8-1.5$ $\mathrm{Hz}), 7.62$ (dt, $1 \mathrm{H}, J=6.6-4.8 \mathrm{~Hz}), 7.38(\mathrm{~d}, 1 \mathrm{H}, J=7.2 \mathrm{~Hz})$, 7.19 (t, $1 \mathrm{H}, J=14.4-6.9 \mathrm{~Hz}), 6.93(\mathrm{q}, 2 \mathrm{H}, J=16.5-7.5 \mathrm{~Hz})$, $5.45(\mathrm{~d}, 1 \mathrm{H}, J=5.7 \mathrm{~Hz}), 5.15-5.10(\mathrm{~m}, 2 \mathrm{H}), 5.00(\mathrm{t}, 1 \mathrm{H}, J=$ $11.1,5.4 \mathrm{~Hz}), 4.53$ (d, 2H, $J=5.4 \mathrm{~Hz}), 4.37-4.29$ (q, 1H, $J=$ $5.4 \mathrm{~Hz}), 4.02(\mathrm{~d}, 2 \mathrm{H}, J=5.1 \mathrm{~Hz}) \mathrm{ppm} .{ }^{13} \mathrm{C}$ NMR (DMSO- $d_{6}$, $75 \mathrm{MHz}): \delta 154.97,152.32,149.66,144.37,138.16,130.69$, 127.56, 126.93, 125.81, 124.37, 120.40, 110.99, 69.55, 67.52, 57.89, 51.98 ppm; MS: $m / z$ value $328.14(\mathrm{M}+1)$

Compound 3H: Colourless solid, yield: $99 \%$. m.p.: $132{ }^{\circ} \mathrm{C}$. Anal. calc. (\%) for $\mathrm{C}_{16} \mathrm{H}_{17} \mathrm{~N}_{5} \mathrm{O}_{3}$ (325.32): C, 58.71; $\mathrm{H}, 5.23$; O, 14.66; N, 21.39. Found(\%): C, 58.69; H, 5.20; O, 14.70; N, 21.38. ${ }^{1} \mathrm{H}$ NMR (DMSO- $\left.d_{6}, 300 \mathrm{MHz}\right): \delta 8.75(\mathrm{~d}, 1 \mathrm{H}, J=4.5$ $\mathrm{Hz}), 8.14(\mathrm{~d}, 1 \mathrm{H}, J=7.8 \mathrm{~Hz}), 8.01(\mathrm{td}, 1 \mathrm{H}, J=7.5-1.5 \mathrm{~Hz})$, $7.55(\mathrm{dt}, 1 \mathrm{H}, J=6.9-5.1 \mathrm{~Hz}), 7.21(\mathrm{~d}, 1 \mathrm{H}, J=7.2 \mathrm{~Hz}), 7.22(\mathrm{t}$,
$1 \mathrm{H}, J=15.3-7.8 \mathrm{~Hz}), 7.00-6.93(\mathrm{~m}, 2 \mathrm{H}), 5.64(\mathrm{~d}, 1 \mathrm{H}, J=6.0$ $\mathrm{Hz}), 5.12-4.83$ (m, 3H), 4.57 (d, 2H, $J=5.4 \mathrm{~Hz}), 4.52-4.46$ $(\mathrm{m}, 1 \mathrm{H}), 4.10(\mathrm{~d}, 2 \mathrm{H}, J=5.1 \mathrm{~Hz}) \mathrm{ppm} .{ }^{13} \mathrm{C}$ NMR (DMSO- $d_{6}$, $75 \mathrm{MHz}): \delta 157.88,155.10,150.14,146.33,137.59,130.75$, 127.66, 127.16, 125.18, 122.18, 120.51, 111.28, 69.44, 67.55, 58.00, 56.25 ppm; MS: $m / z$ value $328.14(\mathrm{M}+1)$.

Single-crystal structure determination: A suitable colourless single crystal of $\mathbf{3 A}$ with dimensions $0.28 \mathrm{~mm} \times 0.26 \mathrm{~mm}$ $\times 0.14 \mathrm{~mm}$ was obtained from methanol solution at room temperature was mounted on a CryoLoop (Hampton Research Corp.); (at IIT Hyderabad) with a layer of light mineral oil and placed in a nitrogen stream at 150(2) K. All measurements were made on an Oxford Supernova X-calibur Eos CCD detector with graphite-monochromatic $\mathrm{CuK}_{\alpha}(1.54184 \AA$ A) radiation, CrysAlisPro, Agilent Technologies, Version 1.171.35.19. The structures were solved by direct methods (SIR92) and refined on F2 by full-matrix least-squares using SHELXL-97 [15]. ORTEP-3 was used to draw the molecule.

Computational procedures: The DFT calculations were performed using the B3LYP three parameter density functional, which includes Becke's gradient exchange correction [16] the Lee, Yang, Parr correlation functional [17] and the Vosko, Wilk, Nusair correlation functional [18]. The geometries of molecules were fully optimized with respect to the energy using the 6$31 \mathrm{~g}(\mathrm{~d}, \mathrm{p})$ basis set using the Gaussian 09W suite.

Molecular docking studies: Crystal structure of DNA was downloaded from Protein Data Bank (PDB ID: 453D). Energy minimized conformations of compound A, B, C and D were generated in FRee On line druG conformation generation (FROG) web-server (Frog2 version), which uses AMMOS force field [19]. The conformation obtained for each of the compound was used further for docking with DNA. The biomolecule was prepared for docking using Autodock tools involved removal of all water molecules from PDB files, addition of polar hydrogen atoms and assigning Gasteiger charges to the proteins. Docking was carried out with Autodock 4.2 Lamarckian Genetic Algorithm, where DNA was enclosed in the grid defined by Auto Grid having $0.375 \AA$ spacing. All other docking parameters were kept as default. PyMol was used for visualization and measurement of distances between the atoms of ligand and the nucleotides of DNA.

\section{RESULTS AND DISCUSSION}

Synthesis and characterization: The synthetic route was started from picolinonitrile $\mathbf{1}$ by following the method published recently [13] to form the tetrazole $\mathbf{2}$ and the structure was confirmed by comparing the analytical data of $\mathbf{2}$ with the reported data. With the compound $\mathbf{2}$ in hand we tried the reaction of the same with 0.5 equivalents of epichlorohydrine in dry DMF in the presence of $\mathrm{K}_{2} \mathrm{CO}_{3}$ at $70{ }^{\circ} \mathrm{C}$ which furnished tetrazoles $\mathbf{3 A}$ and $\mathbf{3 B}$ and the same reaction with 1.0 equivalents of epichlorohydrine was afforded tetrazoles $\mathbf{3 C}$ and $\mathbf{3 D}$ (Scheme-I). The structure of $\mathbf{3 A - 3 D}$ were readily confirmed by observing their ${ }^{13} \mathrm{C}$ NMR which showed chemical shift of the tetrazole carbon atom appearing at about 152.95 or 164.59 ppm in the 1,5- and 2,5-disubstituted tetrazoles, respectively [13]. 


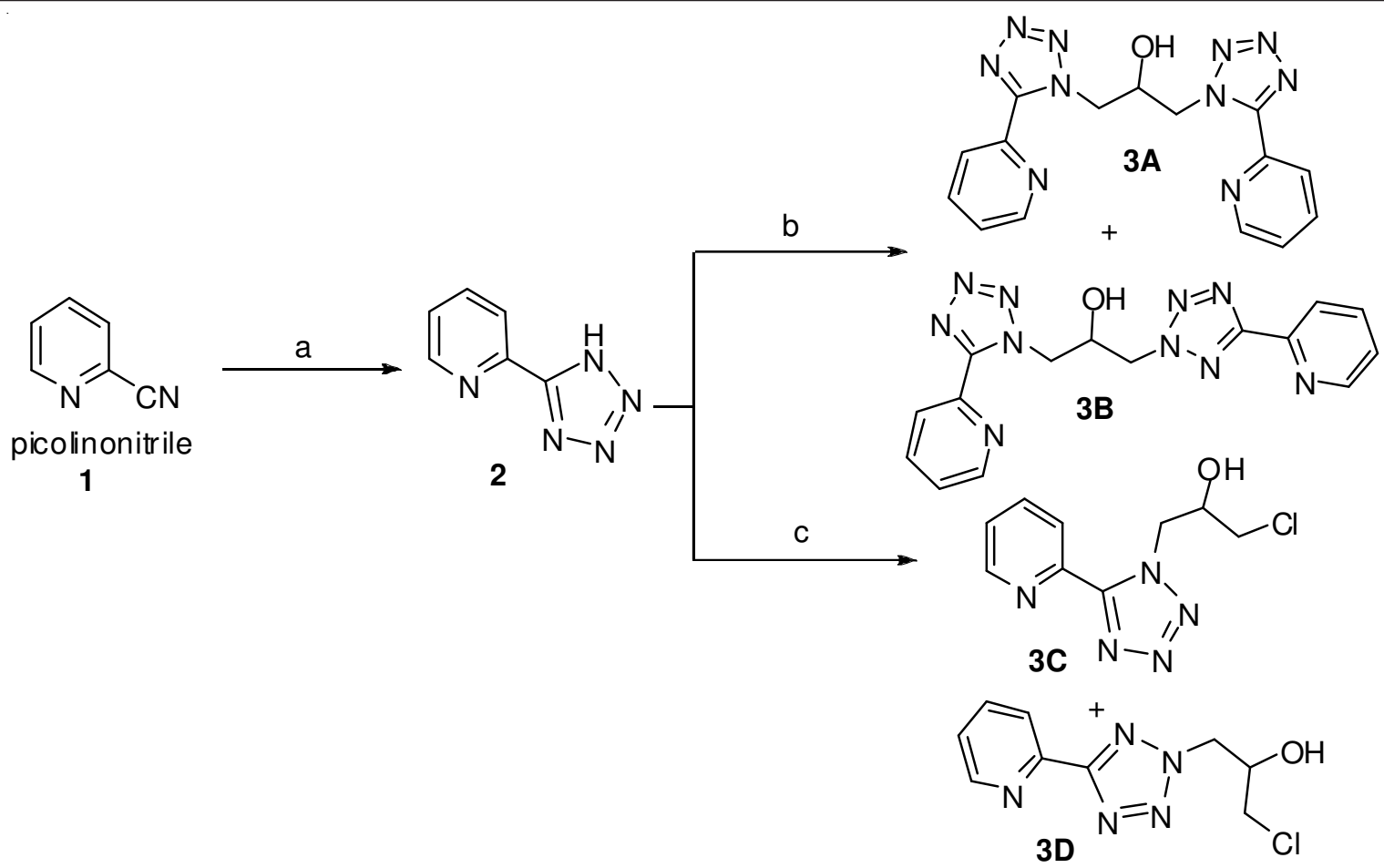

Scheme-I: Synthesis of ligands 3A-3D; Reagents and conditions: a: $\mathrm{NaN}_{3}$ (2eq), $\mathrm{LiCl}(0.5 \mathrm{eq}), \mathrm{NH}_{4} \mathrm{Cl}(2 \mathrm{eq}), \mathrm{DMF}, 110{ }^{\circ} \mathrm{C}, 10 \mathrm{~h}$; b: epichlorohydrine (0.5 eq), $\mathrm{K}_{2} \mathrm{CO}_{3}(2 \mathrm{eq}), \mathrm{DMF}, 70{ }^{\circ} \mathrm{C}, 12 \mathrm{~h}$; c: epichlorohydrine $(1.0 \mathrm{eq}), \mathrm{K}_{2} \mathrm{CO}_{3}(2 \mathrm{eq}), \mathrm{DMF}, 70{ }^{\circ} \mathrm{C}, 12 \mathrm{~h}$

The ${ }^{1}$ H NMR spectra of both $\mathbf{3 A}$ and $\mathbf{3 B}$ (Scheme-I) showed four and eight signals for the pyridyl protons, which indicated the symmetric and unsymmetrical structures respectively. The structures of $\mathbf{3 A}$ and $\mathbf{3 B}$ further confirmed by observing one set of peaks in ${ }^{1} \mathrm{H}$ and ${ }^{13} \mathrm{C}$ NMR spectra of $\mathbf{3 A}$ which indicated a symmetric bis-tetrazole and those two sets of peaks in 3B which indicated unsymmetrical bis-tetrazole. The presence of peak at $\delta 152.9 \mathrm{ppm}$ in the ${ }^{13} \mathrm{C}$-spectrum of $\mathbf{3 A}$ confirmed that it is 1,5-regio isomer at both the tetrazole rings. The presence of peaks at $\delta 165.1 \mathrm{ppm}$ and $\delta 152.9 \mathrm{ppm}$ in the ${ }^{13} \mathrm{C}$-spectrum of 3B confirmed that it is 1,5 and 2,5-regio isomer at the tetrazole rings. In the ${ }^{1} \mathrm{H}$ NMR, the $-\mathrm{OH}$ peak of $\mathbf{3 A}$ is observed as broad multiplet at $\delta 5.88-5.71 \mathrm{ppm}$ whereas it is observed in $\mathbf{3 B}$ as broad singlet at $\delta 5.9 \mathrm{ppm}$. In the case of $\mathbf{3 A}$ the two $-\mathrm{CH}_{2}$ groups attached to tetrazole rings are observed as a single multiplet at $\delta 5.35-5.13 \mathrm{ppm}$ and the -CH-O proton resonated as multiplet at $\delta 4.87-4.78 \mathrm{ppm}$ whereas in the case of $3 \mathbf{B}$ the two $-\mathrm{CH}_{2}$ group protons attached to tetrazole rings along with the $-\mathrm{CH}-\mathrm{O}$ proton are observed as multiplet at $5.23-4.89 \mathrm{ppm}$.

The ${ }^{1} \mathrm{H}$ NMR spectra of both $\mathbf{3 C}$ and $\mathbf{3 D}$ showed four signals for the pyridyl protons. Further the structure of $\mathbf{3 C}$ was confirmed by observing a signal of ${ }^{1} \mathrm{H}$ NMR spectrum at $\delta 5.06-4.91 \mathrm{ppm}(\mathrm{m}, 2 \mathrm{H})$, which is characteristic of $-\mathrm{CH}_{2}$ group adjacent to the tetrazole ring and of 1,5-regio isomer. The -CH signal of - $\mathrm{CH}-\mathrm{OH}$ group is observed as multiplet at $\delta$ 4.45$4.37(1 \mathrm{H})$. A sharp doublet at $\delta 5.83(1 \mathrm{H})$ is observed for $-\mathrm{OH}$ group. Two sets of doublet of doublets (dd) are observed for $-\mathrm{CH}_{2}-\mathrm{Cl}$ group protons at $\delta 3.44$ and 3.62.

The structure of 3D was confirmed by observing a peak of ${ }^{1} \mathrm{H}$ NMR spectrum at $\delta 4.92-4.78(\mathrm{~m}, 2 \mathrm{H})$ slightly downfield compared to the signal of $\mathbf{3 C}$, which is characteristic of $-\mathrm{CH}_{2}$ group adjacent to the tetrazole ring and of 2,5-regio isomer. The - $\mathrm{CH}$ signal of - $\mathrm{CH}-\mathrm{OH}$ group is observed as multiplet at $\delta 4.67-4.58 \mathrm{ppm}(1 \mathrm{H})$ slightly up field compared the signal of 3C. A broad singlet at $\delta 4.16 \mathrm{ppm}(1 \mathrm{H})$ is observed for $-\mathrm{OH}$ group. The protons of $-\mathrm{CH}_{2}-\mathrm{Cl}$ group are appeared as multiplet at $\delta 3.61-3.47 \mathrm{ppm}$. The presence of -OH signal in both the ${ }^{1} \mathrm{H}$ NMR spectra of $\mathbf{3 C}$ and $\mathbf{3 D}$ indicates the opening of epoxide ring in preference to the displacement of chloride ion of epichlorohydrine by the tetrazole ring.

The chloro compounds $\mathbf{3 C}$ and $\mathbf{3 D}$ were reacted with cinnamaldehyde separately to afford $\mathbf{3 E}$ and $\mathbf{3 F}$ respectively (Scheme-II). The ${ }^{1} \mathrm{H}$ NMR spectra of $\mathbf{3 E}$ and $\mathbf{3 F}$ showed peaks for aldehyde protons at $\delta 10.40$ and $\delta 10.48 \mathrm{ppm}$, respectively. The signals corresponding to $-\mathrm{CH}_{2} \mathrm{Cl}$ in $\mathbf{3 C}$ and $\mathbf{3 D}$ are shifted to around $\delta 4.1 \mathrm{ppm}$ region, which confirmed the formation of ether linkage. The aldehydes $\mathbf{3 E}$ and $\mathbf{3 F}$ are further converted into the alcohols $\mathbf{3 G}$ and $\mathbf{3 H}$ respectively by reducing with $\mathrm{NaBH}_{4}$ in methanol (Scheme-II). The formation of alcohols 3G and $\mathbf{3 H}$ are confirmed by observing their ${ }^{1} \mathrm{H}$ NMR spectra which indicated the disappearance of aldehyde proton peaks at $\delta 10.4 \mathrm{ppm}$ and appearance of two protons at around $\delta 4.5$ in both alcohols $\mathbf{3 G}$ and $\mathbf{3 H}$. The studies for the further modifications of aldehyde group of $\mathbf{3 E}$ and $\mathbf{3 F}$ and the formation of metal complexes with all the synthesized ligands and the studies of their properties are in progress.

Further the structure of $\mathbf{3 A}$ is unambiguously assigned by its X-ray single crystal studies. The efforts for the crystallization of rest of the compounds were met with failure.

Crystal structure of $3 \mathrm{~A}$ and comparison with DFT studies of 3A and 3B: Colourless crystals of 1,3-bis-(5-pyridin-2-yltetrazol-1-yl)-propan-2-ol (3A) suitable for X-ray diffraction were obtained from slow evaporation of methanol solution. Crystal data and structure refinements are shown in Table-1. The compound 3A crystallizes in triclinic, space group P-1. The crystal structure comprising of two pyridyl-tetrazoles 
<smiles>C[13CH2]c1cccc(-c2nnnn2CC(O)COc2ccccc2-c2nnnn2CC(O)COc2ccccc2CO)n1</smiles>

\section{E}

$3 G$<smiles></smiles>

Scheme-II: Synthesis of ligands 3E-3H; Reagents and conditions: a and c: Cinnamaldehyde $(1.0 \mathrm{eq}), \mathrm{K}_{2} \mathrm{CO}_{3}(2 \mathrm{eq}), \mathrm{DMF}(0.2 \mathrm{M}), 70{ }^{\circ} \mathrm{C}$, $16 \mathrm{~h} ; \mathrm{b}$ and $\mathrm{d}: \mathrm{NaBH}_{4}(0.5 \mathrm{eq}), \mathrm{CH}_{3} \mathrm{OH}(\mathrm{O} .2 \mathrm{M}), 0{ }^{\circ} \mathrm{C}$ room temperature, $30 \mathrm{~min}$

TABLE-1

CRYSTAL DATA AND STRUCTURE

REFINE SEGMENT FOR COMPOUND 3A

\begin{tabular}{ll}
\hline Identification code & Shelx \\
Empirical formula & $\mathrm{C}_{15} \mathrm{H}_{14} \mathrm{~N}_{10} \mathrm{O}$ \\
Formula weight & 350.36 \\
Temperature & $293(2) \mathrm{K}$ \\
Wavelength & $1.54184 \mathrm{~A}$ \\
Crystal system, Space group & Triclinic, $\mathrm{P}-1$ \\
Unit cell dimensions & $\mathrm{a}=8.9442(7) \AA ; \alpha=83.079(8)^{\circ}$ \\
& $\mathrm{b}=9.2097(9) \AA ; \beta=87.997(7)^{\circ}$ \\
& $\mathrm{c}=11.3558(10) \AA ; \gamma=61.355(9)^{\circ}$ \\
Volume & $814.68(12) \AA^{3}$ \\
Z, Calculated density & $2,1.428 \mathrm{Mg} / \mathrm{m}^{3}$ \\
Absorption coefficient & $0.833 \mathrm{~mm} \mathrm{~m}^{-1}$ \\
F(000) & 364 \\
Crystal size & $0.28 \mathrm{~mm} \times 0.26 \mathrm{~mm} \times 0.14 \mathrm{~mm}$ \\
Theta range for data collection & 3.92 to 70.71 deg. \\
Limiting indices & $-10<=\mathrm{h}<=10,-11<=\mathrm{k}<=10$, \\
& $-13<=\mathrm{l}<=13$ \\
Reflections collected/unique & $6111 / 3032[\mathrm{R}($ int $)=0.0213]$ \\
Completeness to theta & $70.7196 .9 \%$ \\
Absorption correction & $\mathrm{Semi}-\mathrm{empirical}$ form equivalents \\
Max. and min. transmission & 1.00000 and 0.88373 \\
Refinement method & Full-matrix least-squares on $\mathrm{F}^{2}$ \\
Data/restraints/parameters & $3032 / 0 / 237$ \\
Goodness-of-fit on $\mathrm{F}^{2}$ & 1.068 \\
Final R indices [I $2 \sigma(\mathrm{I})]$ & $\mathrm{R} 1=0.0547, \mathrm{wR} 2=0.1510$ \\
$\mathrm{R}$ indices (all data) & $\mathrm{R} 1=0.0592, \mathrm{wR} 2=0.1570$ \\
\hline
\end{tabular}

moieties linked by 2-propanol chain through tetrazole $\mathrm{N}$ moieties at the N5 and N6 site to generate a dimer (Fig. 1). Selected bond distances and bond angles are listed in Table-2. Each of the pyridyl tetrazole moiety lie perpendicular to the other, while tetrazole ring is coplanar with the pyridyl ring $[20,21]$. The distance of centers of gravity of the two rings

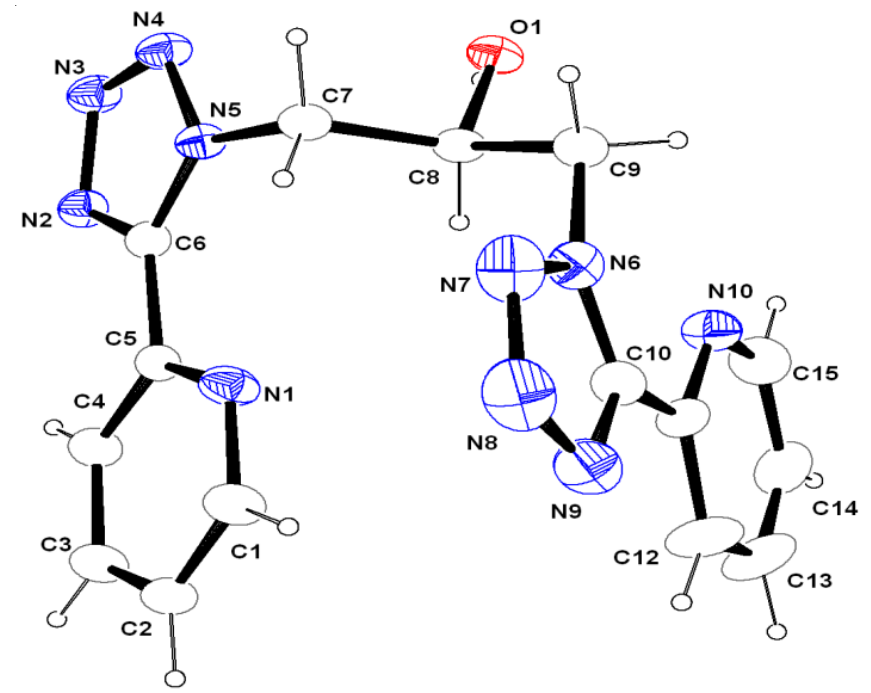

Fig. 1. Ortep diagram of compound $\mathbf{3 A}$

TABLE-2

SELECTED BOND LENGTHS $(\AA)$ AND BOND ANGLES $\left({ }^{\circ}\right)$ FOR 3A AND 3B COMPOUNDS

\begin{tabular}{|c|c|c|c|c|c|c|c|}
\hline Bond length & $\begin{array}{c}\text { Exp. (X-ray } \\
\text { of } \mathbf{3 A})\end{array}$ & $\begin{array}{l}\text { B3LYP/6- } \\
31 \mathrm{G} \text { of } \mathbf{3 A}\end{array}$ & $\begin{array}{c}\text { B3LYP/6-31G } \\
\text { of } \mathbf{3 B}\end{array}$ & Bond angles & $\begin{array}{c}\text { Exp. } \\
\text { (X-ray of } \mathbf{3 A})\end{array}$ & $\begin{array}{l}\text { B3LYP/6- } \\
31 \mathrm{G} \text { of } \mathbf{3 A}\end{array}$ & $\begin{array}{l}\text { B3LYP/6- } \\
31 \mathrm{G} \text { of } \mathbf{3 B} \\
\end{array}$ \\
\hline N5- C6 & 1.347 & 1.345 & 1.3508 & C6 -N5- N4 & 108.0 & 107.16 & 112.9 \\
\hline N5- C7 & 1.465 & 1.472 & 1.4634 (N4-C7) & C6- N5- C7 & 131.8 & 133.56 & $102.34(\mathrm{C} 6-\mathrm{N} 5-\mathrm{N} 4)$ \\
\hline N5- N4 & 1.349 & 1.345 & 1.3744 & N4-N5-C7 & 119.6 & 118.06 & 121.46 (N5-N4-C7) \\
\hline O1- C8 & 1.414 & 1.431 & 1.4603 & N5-C7-C8 & 109.7 & 110.28 & 110.94 (N4-C7-C8) \\
\hline $\mathrm{N} 2-\mathrm{C} 6$ & 1.322 & 1.315 & 1.3815 & $\mathrm{O} 1-\mathrm{C} 8-\mathrm{C} 7$ & 109.9 & 111.14 & 113.22 \\
\hline N6 - C9 & 1.465 & 1.472 & 1.4824 & $\mathrm{O} 1-\mathrm{C} 8-\mathrm{C} 9$ & 107.4 & 103.42 & 109.42 \\
\hline $\mathrm{C} 8-\mathrm{C} 9$ & 1.521 & 1.535 & 1.536 & C10-N6-N7 & 108.8 & 107.28 & 107.75 \\
\hline C8- C7 & 1.519 & 1.530 & 1.557 & C9-N6-N7 & 119.5 & 119.10 & 121.18 \\
\hline C6 - C5 & 1.473 & 1.465 & 1.460 & C9-N6-C10 & 131.7 & 133.58 & 131.05 \\
\hline N6 -N7 & 1.342 & 1.355 & 1.414 & N5-C6-C5 & 127.3 & 126.69 & 124.92 \\
\hline N10- C11 & 1.321 & 1.326 & 1.352 & N10-C11-C10 & 117.3 & 114.81 & 118.01 \\
\hline C11- C10 & 1.479 & 1.472 & 1.460 & C11-C10-N9 & 124.3 & 123.26 & 122.89 \\
\hline N2- C6 & 1.322 & 1.315 & 1.381 & C7-C8-C9 & 111.6 & 113.24 & 105.97 \\
\hline C5 -N1 & 1.330 & 1.328 & 1.355 & - & - & - & - \\
\hline
\end{tabular}


through C8-O1 plane is $2.440 \AA(\mathrm{C} 8---\mathrm{N} 5) ; 3.397 \AA$ (C8--N1) and $2.454 \AA$ (C8---N6); $3.200 \AA$ (C8---N10). Dihedral angle of N5-C7-C8-O1 is -52.84 $\AA$ and N6-C9-C8-O1 is $165.29 \AA$ suggesting that two pyridyl tetrazole moieties are arranged in different planes. The close packing structure of 3A is shown in Fig. 1. The structure displayed strong intermolecular hydrogen bonding between $\mathbf{O 1}$ of one molecule and $\mathbf{N} 2$ of other molecule establishing a closed circle structure to form dimeric arrangement [22].

Hirshfeld interactions studies: The interactions are further studied by Hirshfeld interactions studies. Hirshfeld surface and 2D fingerprint plot is generated for the crystal data of compound 3A using crystal explorer v. 3.1. which are shown in Fig. 2. The colour mapping and the shape of the three dimensional Hirshfeld surfaces of $\mathbf{3 A}$ showed the different intermolecular interactions present in the crystal packing. The red spots on the surfaces indicated the close-contact interactions and mainly responsible for the molecular packing in the crystal. The crystal packing of $\mathbf{3 A}$ is mainly controlled by dominant interactions involving $\mathrm{O}-\mathrm{H} \cdots \mathrm{N}$ and $\mathrm{N} \cdots \mathrm{H}$ contacts, which are observed as red spots on the Hirshfeld surfaces [23,24]. The percentage of surface area having close contact reciprocal data with atom $v s$. atom is given in Table-3. From the data it is clear that the $\mathrm{H}$-bonding interactions are major with $\mathrm{N} \cdots \mathrm{H} ; \mathrm{C} \cdots \mathrm{H}$ of pyridine moiety and $\mathrm{O} \cdots \mathrm{H}$ interactions.

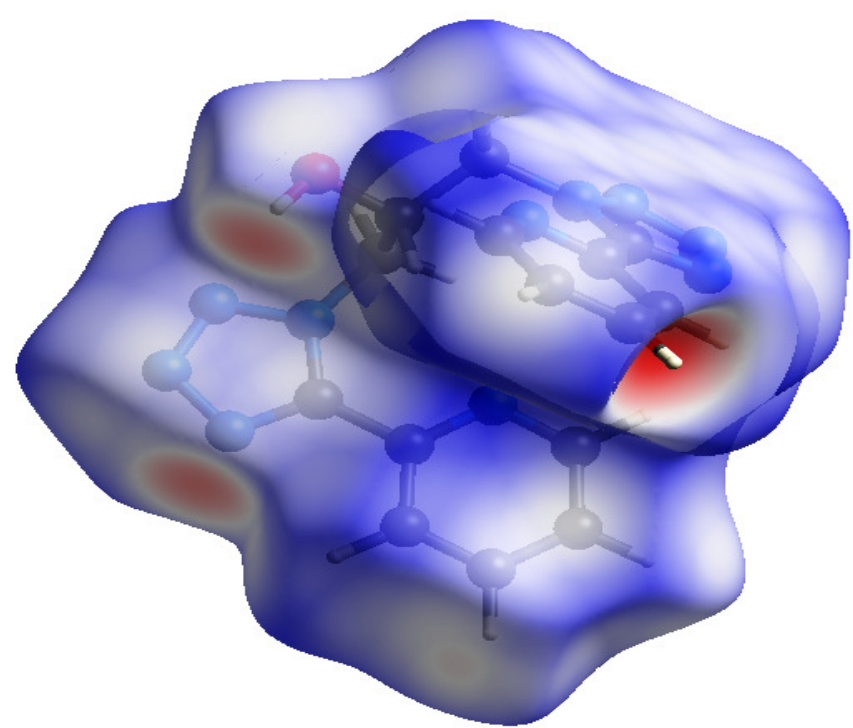

TABLE-3

MAJOR PERCENTAGE INTERACTIONS IN COMPOUND 3A

\begin{tabular}{ccr}
\hline S. No. & Interaction & $\%$ \\
\hline 1 & N-H & 33.2 \\
2 & N-C & 6.4 \\
3 & N-N & 3.8 \\
4 & O-H & 4.4 \\
5 & H-H & 32.3 \\
6 & C-H & 17.8 \\
7 & C-N & 3.3 \\
\hline
\end{tabular}

The X-ray crystallographic bond lengths and the bond angles of $\mathbf{3 A}$ are compared with calculated values with the B3LYP/6-311G** method for the isolated molecule. Observation of overall data is in good agreement (about $\pm 0.01 \AA$ for bond lengths and about $\pm 1.5^{\circ}$ bond angle), except when atoms $\mathrm{O} 1$, $\mathrm{C} 7, \mathrm{C} 8$ and $\mathrm{C} 9$ are involved. The dependence of the calculated structure upon the DFT functional (B3LYP) and basis sets (6$311 \mathrm{G}^{* *}$ ) is displayed in Fig. 3 as overlaying with the $\mathrm{X}$-ray structure.

HOMO and LUMO studies of 3A and 3B: The main contribution to the maximum absorption band is the HOMO (highest occupied molecular orbital) - LUMO (lowest unoccupied molecular orbital) transitions, whose isovalue surfaces are depicted in Fig. 4. It is observed from Fig. 4 that the HOMO is

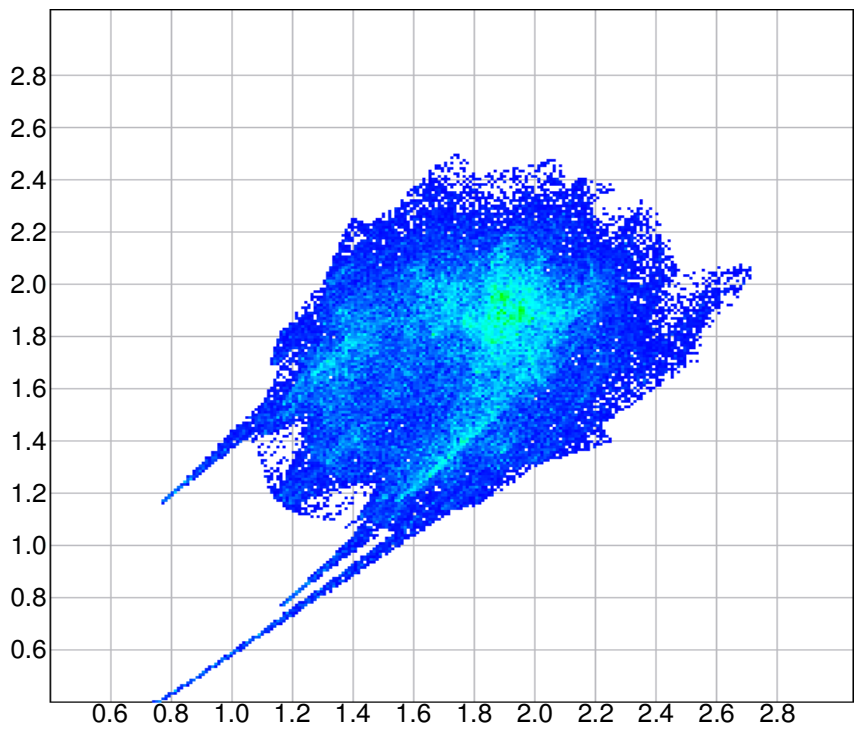

Fig. 2. Hirshfeld surface and $2 \mathrm{D}$ fingerprint plot associated with compound $\mathbf{3 A}$
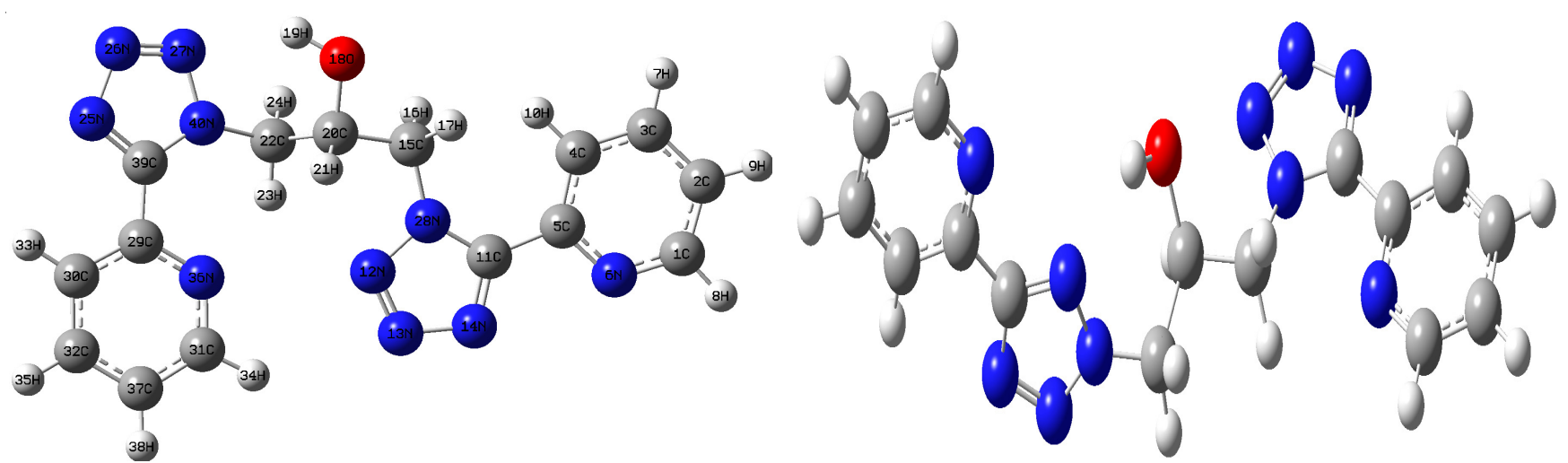

Fig. 3. Optimized structure of compound $\mathbf{3 A}$ and $\mathbf{3 B}$ at B3LYP/6-311G** 


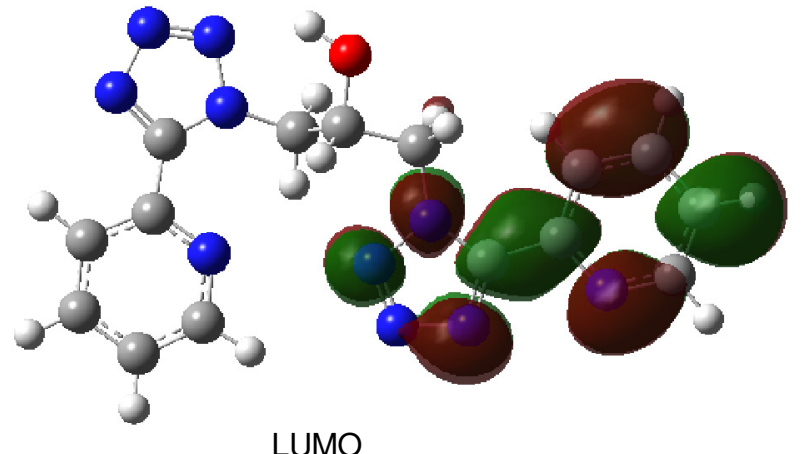

LUMO

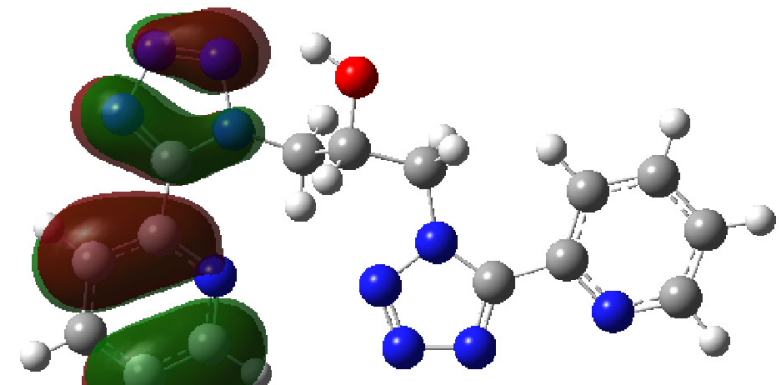

$\mathrm{HOMO}$

3A
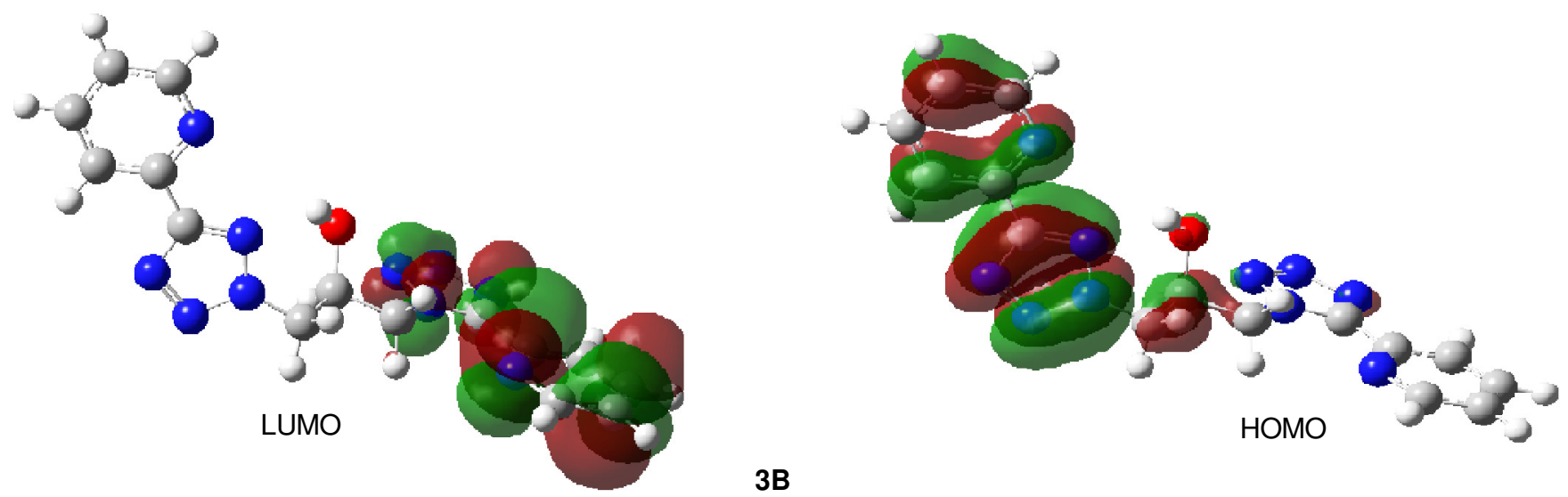

Fig. 4. Isovalue surfaces of the HOMO (highest occupied molecular orbital) and LUMO (lowest unoccupied molecular orbital) of HOMO and LUMO of $\mathbf{3 A}$ and $\mathbf{3 B}$ computed at the B3LYP/6-311G** level

localized over the vertical pyridyl-tetrazole rings, whereas the LUMO is localized on the horizontal pyridyl-tetrazole fragment. The HOMO and LUMO energies of $\mathbf{3 A}$ and $\mathbf{3 B}$ are -0.367 , -0.324 and $0.046,0.042$ with HOMO-LUMO energy gaps $0.320,0.282$, respectively.

Molecular electrostatic potential (MEP): The molecular electrostatic potential is a useful property to determine the preferred sites for the nucleophilic and electrophilic attack and hydrogen-bond interactions [25,26]. The H-donor and $\mathrm{H}-$ acceptor properties are related to the positive and negative regions, respectively. Thus, the formation of hydrogen bonds can be related to the electrostatic potentials [27]. Being a real physical property, electrostatic potential can be calculated by both experimental i.e. X-ray diffraction and computational methods [28]. In most of the MEPs, the regions with the most negative charge values, shown in red colour, are assigned as the preferred site for electrophilic reactions, while the region of highly positive charge, shown in blue, is the preferred site for nucleophilic attack [29]. The molecular electrostatic potential map of compound $\mathbf{3 A}$ computed at B3LYP/6-311G** is shown in Fig. 5. The negative electrostatic region is localized on N4, N5, O1, N8, N9 and N10 atoms. However, the most positive region (blue) is localized on the pyridine hydrogen atom being the highest positive region, which indicates the possible site for nucleophilic attack.

Molecular docking: Molecular docking studies provide some insight into the interactions between the macromolecule and ligand. Fig. 6 shows the docked conformation of compounds $\mathbf{3 A}, \mathbf{3 B}, \mathbf{3 G}$ and $\mathbf{3 H}$ with ct-DNA. In the final docked conformation, all the molecule exists in a crescent shape, which
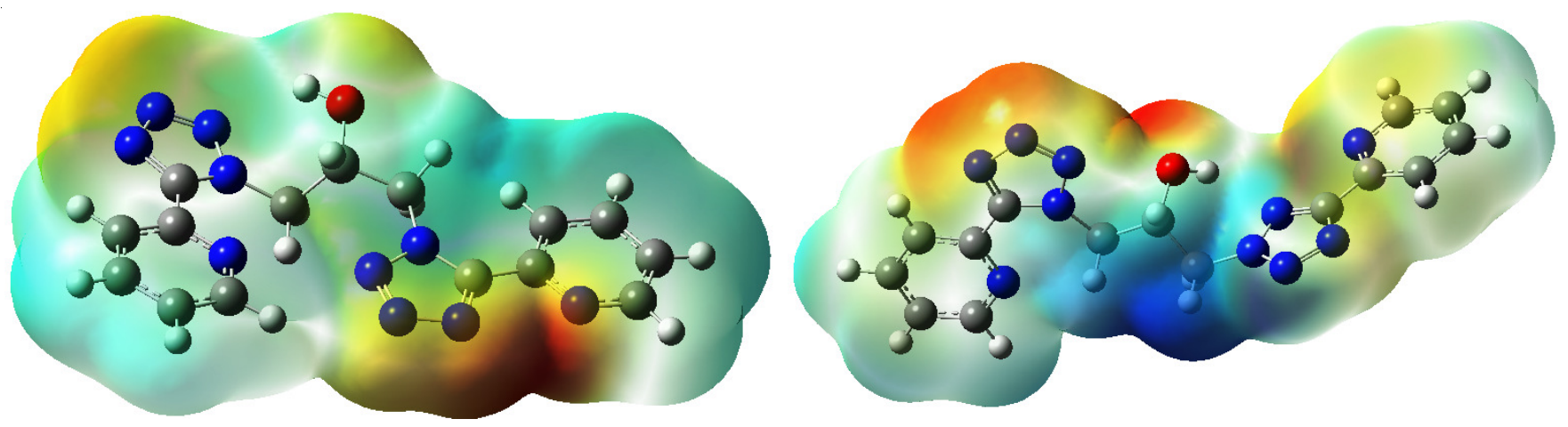

Fig. 5. Molecular electrostatic potential map (MEP) calculated at PBE1PBE/6-311G (d,p) level 

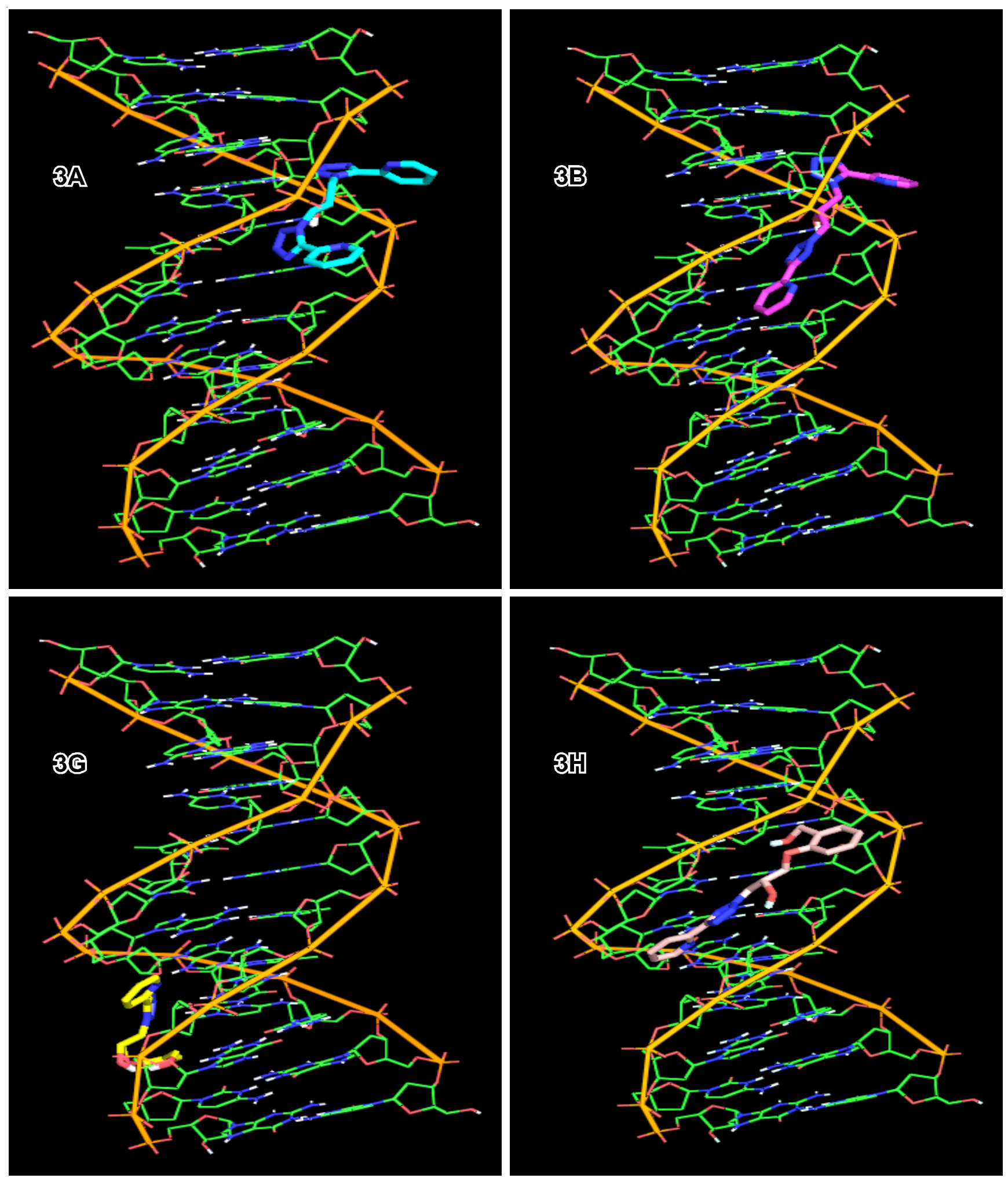

Fig. 6. The docked conformations of compounds $\mathbf{3 A}, \mathbf{3 B}, \mathbf{3 G}$ and $\mathbf{3 H}$ with ct-DNA

is complementary to the natural curvature of the minor groove of B-DNA [30,31]. The docked structure as shown in Fig. 6 suggests that the molecules could fit within the minor groove of ct-DNA. Minor groove binders generally have aromatic rings connected by single bonds that allow for torsional rotation in order to fit into the narrower helical curvature of the groove comprising the A-T region with displacement of water molecules. The narrower A-T regions compared to $\mathrm{G}-\mathrm{C}$ regions produce a better fit of these types of molecules into the minor groove and lead to vander Waals interaction with the DNA functional groups that define the groove. Hydrogen bonding from the C- 2 carbonyl oxygen of T or the N-3 nitrogen of A to the minor groove binders is important [32] which is seen from the distance between the bonded atoms of ct-DNA and the compounds as in Table-4. Also there are extensive van der Waals contacts between the docked molecules and the floor and walls 


\begin{tabular}{|c|c|c|c|c|c|}
\hline \multicolumn{6}{|c|}{$\begin{array}{c}\text { TABLE-4 } \\
\text { DISTANCES (Å) BETWEEN POLAR NEIGHBORS OF DNA AND }\end{array}$} \\
\hline DNA & & Compound $\mathbf{3 A}$ & Compound $\mathbf{3 B}$ & Compound 3G & Compound $\mathbf{3 H}$ \\
\hline \multirow[t]{4}{*}{ G4 2-NH } & & & & $3.13[1-\mathrm{N}(\mathrm{B})]$ & \\
\hline & & & & $3.02[2-\mathrm{N}(\mathrm{B})]$ & \\
\hline & & & & $3.06[3-\mathrm{N}(\mathrm{B})]$ & \\
\hline & & & & $3.20[4-\mathrm{N}(\mathrm{B})]$ & \\
\hline \multirow[t]{4}{*}{ A5 } & N3 & & & $2.97[1-\mathrm{N}(\mathrm{A})]$ & \\
\hline & & & & $3.01[4-\mathrm{N}(\mathrm{B})]$ & \\
\hline & 1'-O of sugar & & & $2.73[3-\mathrm{N}(\mathrm{B})]$ & \\
\hline & & & & $3.05[4-\mathrm{N}(\mathrm{B})]$ & \\
\hline A6 1'-O of sugar & & & & & $3.01[1-\mathrm{N}(\mathrm{A})]$ \\
\hline \multirow[t]{2}{*}{$\mathrm{T} 7(2-\mathrm{C}=\mathrm{O})$} & & & & & $3.41[1-\mathrm{N}(\mathrm{B})]$ \\
\hline & & & & & $2.67[5-\mathrm{N}(\mathrm{B})]$ \\
\hline \multirow[t]{3}{*}{$\mathrm{T} 8$} & 1'-O of sugar & & & & $3.34[1-\mathrm{N}(\mathrm{B})]$ \\
\hline & & & & & $3.40[5-\mathrm{N}(\mathrm{B})]$ \\
\hline & $2-\mathrm{C}=\mathrm{O}$ & $2.90[3-\mathrm{N}(\mathrm{B})]$ & $2.80[3-\mathrm{N}(\mathrm{C})]$ & & $2.93\left[2-\mathrm{C}-\mathrm{CH}_{2} \mathrm{O}(\mathrm{C})\right]$ \\
\hline \multirow[t]{5}{*}{ C9 } & 1'-O of sugar & $3.39[1-\mathrm{N}(\mathrm{B})]$ & $3.33[1-\mathrm{N}(\mathrm{C})]$ & & $2.58[1-\mathrm{C}-\mathrm{O}(\mathrm{C})]$ \\
\hline & & $3.34[2-\mathrm{N}(\mathrm{B})]$ & $3.49[2-\mathrm{N}(\mathrm{C})]$ & & $3.49\left[2-\mathrm{C}-\mathrm{CH}_{2} \mathrm{O}(\mathrm{C})\right]$ \\
\hline & & $3.45[3-\mathrm{N}(\mathrm{B})]$ & $3.28[3-\mathrm{N}(\mathrm{C})]$ & & \\
\hline & & & $3.02[5-\mathrm{N}(\mathrm{C})]$ & & \\
\hline & $2-\mathrm{C}=\mathrm{O}$ & $3.08[2-\mathrm{N}(\mathrm{B})]$ & $2.99\left[2^{\prime}-\mathrm{O}\right]$ & & \\
\hline \multirow[t]{4}{*}{ G10 } & 2- $\mathrm{NH}_{2}$ & & $3.04[3-\mathrm{N}(\mathrm{B})]$ & & \\
\hline & N3 & & $3.12[2-\mathrm{N}(\mathrm{B})]$ & & \\
\hline & & & $3.24[3-\mathrm{N}(\mathrm{B})]$ & & \\
\hline & 1'-O of sugar & & $3.34[2-\mathrm{N}(\mathrm{B})]$ & & \\
\hline \multirow[t]{3}{*}{ C11 1'-O of sugar } & & & $3.36[2-\mathrm{N}(\mathrm{B})]$ & & \\
\hline & & & $2.79[3-\mathrm{N}(\mathrm{B})]$ & & \\
\hline & & & $2.73[4-\mathrm{N}(\mathrm{B})]$ & & \\
\hline \multirow[t]{4}{*}{ G16 2- $\mathrm{NH}_{2}$} & & $2.63[2-\mathrm{N}(\mathrm{C})]$ & $3.47[1-\mathrm{N}(\mathrm{B})]$ & & \\
\hline & & $3.19[3-\mathrm{N}(\mathrm{C})]$ & $2.88[2-\mathrm{N}(\mathrm{B})]$ & & \\
\hline & & & $3.17[3-\mathrm{N}(\mathrm{B})]$ & & \\
\hline & & & $3.19[2 '-\mathrm{O}]$ & & \\
\hline \multirow[t]{5}{*}{ A17 } & N3 & $3.33[2-\mathrm{N}(\mathrm{B})]$ & $2.70\left[2^{\prime}-\mathrm{O}\right]$ & & $3.20\left[2-\mathrm{C}-\mathrm{CH}_{2} \mathrm{O}(\mathrm{C})\right]$ \\
\hline & & $3.05\left[2^{\prime}-\mathrm{O}\right]$ & $3.45[2-\mathrm{N}(\mathrm{C})]$ & & \\
\hline & $1^{\prime}-\mathrm{O}$ of sugar & $3.40[2-\mathrm{N}(\mathrm{C})]$ & & & \\
\hline & & $2.80[3-\mathrm{N}(\mathrm{C})]$ & & & \\
\hline & & $3.19[4-\mathrm{N}(\mathrm{C})]$ & & & \\
\hline \multirow[t]{5}{*}{ A18 } & N3 & $2.65[3-\mathrm{N}(\mathrm{B})]$ & $3.41[2-\mathrm{N}(\mathrm{C})]$ & & $2.84\left[2-\mathrm{C}-\mathrm{CH}_{2} \mathrm{O}(\mathrm{C})\right]$ \\
\hline & & $3.26[4-\mathrm{N}(\mathrm{B})]$ & $2.71[3-\mathrm{N}(\mathrm{C})]$ & & \\
\hline & $1^{\prime}-\mathrm{O}$ of sugar & $3.36[2-\mathrm{N}(\mathrm{B})]$ & 3.09 [2'-O] & & $3.38\left[2-\mathrm{C}-\mathrm{CH}_{2} \mathrm{O}(\mathrm{C})\right]$ \\
\hline & & $3.49[3-\mathrm{N}(\mathrm{B})]$ & $3.14[2-\mathrm{N}(\mathrm{C})]$ & & \\
\hline & & $2.75\left[2^{\prime}-\mathrm{O}\right]$ & & & \\
\hline \multirow[t]{3}{*}{ T19 } & $2-\mathrm{C}=\mathrm{O}$ & & & & $3.06[1-\mathrm{N}(\mathrm{B})]$ \\
\hline & & & & & $2.78[5-\mathrm{N}(\mathrm{B})]$ \\
\hline & 1'-O of sugar & $3.28[4-\mathrm{N}(\mathrm{B})]$ & & & $3.35\left[2^{\prime}-\mathrm{O}\right]$ \\
\hline \multirow[t]{3}{*}{$\mathrm{T} 20$} & $(2-\mathrm{C}=\mathrm{O})$ & & & & $3.12[1-\mathrm{N}(\mathrm{A})]$ \\
\hline & 1'-O of sugar & & & & $3.33[3-\mathrm{N}(\mathrm{B})]$ \\
\hline & & & & & $3.36[5-\mathrm{N}(\mathrm{B})]$ \\
\hline $\mathrm{C} 21$ & $2-\mathrm{C}=\mathrm{O}$ & & & $3.05[1-\mathrm{N}(\mathrm{A})]$ & \\
\hline \multirow[t]{2}{*}{ G22 } & N3 & & & $2.97\left[2-\mathrm{C}-\mathrm{CH}_{2} \mathrm{O}(\mathrm{C})\right]$ & \\
\hline & 1'-O of sugar & & & $3.31\left[2-\mathrm{C}-\mathrm{CH}_{2} \mathrm{O}(\mathrm{C})\right]$ & \\
\hline \multirow[t]{3}{*}{$\mathrm{C} 23$} & N1 & & & $3.41\left[2-\mathrm{C}-\mathrm{CH}_{2} \mathrm{O}(\mathrm{C})\right]$ & \\
\hline & 1'-O of sugar & & & $3.03[1-\mathrm{C}-\mathrm{O}(\mathrm{C})]$ & \\
\hline & & & & $2.41\left[2-\mathrm{C}-\mathrm{CH}_{2} \mathrm{O}(\mathrm{C})\right]$ & \\
\hline
\end{tabular}

Note: Rings have been mentioned within parenthesis for all the ligands.

of the minor groove suggesting that this type of interaction contributes to the stabilization of the complex. The estimated free energy of binding at $298.15 \mathrm{~K}$ was found to be $-8.90 \mathrm{kcal} /$ $\mathrm{mol},-10.06 \mathrm{kcal} / \mathrm{mol},-6.30 \mathrm{kcal} / \mathrm{mol}$ and $-7.50 \mathrm{kcal} / \mathrm{mol}$ for compound $\mathbf{3 A}, \mathbf{3 B}, \mathbf{3 G}$ and $\mathbf{3 H}$ respectively.

\section{Conclusion}

A new series of pyridyl-tetrazole analogues $\mathbf{3 A}-\mathbf{H}$ were synthesized and characterized with spectroscopic techniques.
Compound 3A was crystallized and its crystal structure was confirmed by X-ray diffraction which proved the two pyridyl tetrazole moieties lie perpendicular to each other, while tetrazole ring is coplanar to the pyridyl ring. It has shown strong intermolecular hydrogen bonding between $\mathbf{O 1}$ of the one molecule and $\mathbf{N} 2$ of the other molecule establishing a closed ring structure to form dimer. DFT calculations were carried out on compounds 3A and 3B using B3LYP/6-11G** method. The optimized structure, bond lengths and bond angles are comparable. Hirshfeld 
interaction studies and molecular electrostatic potential map suggest that negative electrostatic region is localized on N4, N5, O1, N8, N9 and N10 atoms of $\mathbf{3 A}$ and $\mathbf{3 B}$. The molecular docking studies of $\mathbf{3 A}, \mathbf{3 B}, \mathbf{3 G}$ and $\mathbf{3 H}$ revealed that all the compounds bind with $c t$-DNA and exist in crescent shapes.

Supplementary information (SI): CCDC 1415988 contains supplementary crystallographic data (excluding structure factors) for the structure reported in this article. These data can be obtained free of charge via http://www.ccdc.cam.ac.uk/ data_request/cif, by e-mailing data_request@ ccdc.cam.ac.uk or by contacting The Cambridge Crystallographic Data Centre, 12 Union Road, Cambridge CB2 1EZ, UK; fax: +441223 336033. Supplementary data of ${ }^{1} \mathrm{H}$ and ${ }^{13} \mathrm{C}$ NMR spectra associated with this article can be found, in the online version, at www.ias.ac.in/chemsci.

\section{ACKNOWLEDGEMENTS}

The authors are thankful to the financial assistances from DST with project No.SB/FT/CS-034/2012 (SERB, New Delhi, India) and UGC with project F.No.42-306/2013 (SR) (New Delhi, India).

\section{REFERENCES}

1. L.M.T. Frija, R. Fausto, R.M.S. Loureiro and M.L.S. Cristiano, J. Mol. Catal. Chem., 305, 142 (2009); https://doi.org/10.1016/j.molcata.2008.12.007.

2. N. Fischer, D. Izsak, T.M. Klapötke, S. Rappenglück and J. Stierstorfer, Chem. Eur. J., 18, 4051 (2012) https://doi.org/10.1002/chem.201103737.

3. 3 V. Subramanian, J.S. Knight, S. Parelkar, L. Anguish, S.A. Coonrod, M.J. Kaplan and P.R. Thompson, J. Med. Chem., 58, 1337 (2015); https://doi.org/10.1021/jm501636x.

4. D. Fischer, T.M. Klapötke and J. Stierstorfer, Angew. Chem. Int. Ed., 54, 10299 (2015); https://doi.org/10.1002/anie.201502919.

5. D.J. Carini, J.V. Duncia, P.E. Aldrich, A.T. Chiu, A.L. Johnson, M.E. Pierce, W.A. Price, J.B. Santella and G.J. Wells, J. Med. Chem., 34, 2525 (1991); https://doi.org/10.1021/jm00112a031.

6. E.A. Popova, R.E. Trifonov and V.A. Ostrovskii, Arkivoc, 45 (2012); https://doi.org/10.3998/ark.5550190.0013.102.

7. G. Aromí, L.A. Barrios, O. Roubeau and P. Gamez, Coord. Chem. Rev., 255, 485 (2011); https://doi.org/10.1016/j.ccr.2010.10.038.

8. J.H. Lee, H. Lee, S. Seo, J. Jaworski, M.L. Seo, S. Kang, J.Y. Lee and J.H. Jung, New J. Chem., 35, 1054 (2011); https://doi.org/10.1039/c0nj00840k.

9. Y. Tao, J.R. Li, Z. Chang and X.H. Bu, Cryst. Growth Des., 10, 564 (2010); https://doi.org/10.1021/cg900934u.
10. G.W. Yang, Y.S. Ma, Q.Y. Li, Y. Zhou, G.Q. Gu, Y. Wu and R.X. Yuan, J. Coord. Chem., 62, 1766 (2009); https://doi.org/10.1080/00958970802705893.

11. S.-M. Zhang, Z. Chang, T.-L. Hu and X.-H. Bu, Inorg. Chem., 49, 11581 (2010); https://doi.org/10.1021/ic1017467.

12. U. Sheridan, J.F. Gallagher, M.J. Bjerrum, A. Fleming, F. Kelleher and J. McGinley, Inorg. Chim. Acta, 421, 200 (2014); https://doi.org/10.1016/j.ica.2014.05.028.

13. S. Mustafa, B.U. Rao, M.S. Surendrababu, K.K. Raju and G.N. Rao, Chem. Biodivers., 12, 1516 (2015); https://doi.org/10.1002/cbdv.201400369.

14. M. Veronelli, S. Dechert, S. Demeshko and F. Meyer, Inorg. Chem., 54, 6917 (2015); https://doi.org/10.1021/acs.inorgchem.5b00898.

15. G.M. Sheldrick, SHELXS-97, Program of Crystal Structure Solution, University of Göttingen, Germany (1997).

16. M.F. Wu, M.S. Wang, S.P. Guo, F.K. Zheng, H.F. Chen, X.M. Jiang, G.N. Liu, G.C. Guo and J.S. Huang, Cryst. Growth Des., 11, 372 (2011); https://doi.org/10.1021/cg100817s.

17. T. Mavromoustakos, A. Kolocouris, M. Zervou, P. Roumelioti, J. Matsoukas and R. Weisemann, J. Med. Chem., 42, 1714 (1999); https://doi.org/10.1021/jm980499w.

18. R.A. Powers and B.K. Shoichet, J. Med. Chem., 45, 3222 (2002); https://doi.org/10.1021/jm020002p.

19. T. Pencheva, D. Lagorce, I. Pajeva, B.O. Villoutreix and M.A. Miteva, BMC Bioinform., 9, 438 (2008); https://doi.org/10.1186/1471-2105-9-438.

20. B.K. Tripuramallu, R. Kishore and S.K. Das, Inorg. Chim. Acta, 368, 132 (2011); https://doi.org/10.1016/j.ica.2010.12.062.

21. H. Zhao, Z.R. Qu, H.Y. Ye and R.G. Xiong, Chem. Soc. Rev., 37, 84 (2008); https://doi.org/10.1039/B616738C

22. S.M. Mobin and A. Mohammad, Dalton Trans., 43, 13032 (2014); https://doi.org/10.1039/C4DT01312C.

23. R. Soman, S. Sujatha and C. Arunkumar, J. Fluor. Chem., 163, 16 (2014); https://doi.org/10.1016/j.jfluchem.2014.04.002.

24. A. Farukh and M. Muddassir, J. Photochem. Photobiol. B: Biol., 101, 37 (2010).

25. E. Scrocco and J. Tomasi, Adv. Quantum Chem., 11, 115 (1978); https://doi.org/10.1016/S0065-3276(08)60236-1.

26. F.J. Luque, J.M. Lopez and M. Orozco, Theor. Chem. Acc., 103, 343 (2000); https://doi.org/10.1007/s002149900013.

27. N. Okulik and A.H. Jubert, Internet Electron. J. Mol. Des., 4, 17 (2005).

28. S.J. Grabowski, ed. J. Leszczynski, Hydrogen Bonding-New Insights, Challenges and Advances in Computational Chemistry and Physics, Springer, vol. 3 (2006).

29. P. Politzer and D.G. Truhlar, Chemical Applications of Atomic and Molecular Electrostatic Potentials, Plenum: New York (1981).

30. B.S. Reddy, S.M. Sondhi and J.W. Lown, Pharmacol. Ther, 84, 1 (1999); https://doi.org/10.1016/S0163-7258(99)00021-2.

31. S. Neidle, Nat. Prod. Rep., 18, 291 (2001); https://doi.org/10.1039/a705982e.

32. R.B. Silverman, The Organic Chemistry of Drug Design and Drug Action, Academic press, USA, edn 2, pp. 345-346 (2004). 